\title{
CONVEX AND CONCAVE: CONCEPTUAL BOUNDARIES IN PSYCHOLOGY, NOW AND THEN (BUT MAINLY THEN)
}

By Rick Rylance

My TITLE is derived from G. H. Lewes's psychological magnum opus Problems of Life and Mind (1874-79). Lewes's image is a metaphor for the relation of mind to brain, or more generally of the mind to the nervous system: "every mental phenomenon has its corresponding neural phenomenon (the two being as convex and concave surfaces of the same sphere, distinguishable yet identical)" (Problems: First Series 1: 112). His point is that, though the two entities can be analytically distinguished, they are as necessarily linked as the two surfaces of a bending plane. Like the recto and verso of a sheet of paper, or signifier and signified in the linguistic sign, one can make an interpretative separation of the two, but not an ontological one. It is a characteristically deft metaphor by Lewes to express a notoriously vexed relationship, not only in Victorian psychology but also in modern thinking today.

Lewes's metaphor implicitly challenges several orthodoxies of nineteenth-century psychological theory, which I will describe shortly. But it does so by a metaphor that is, of itself, without boundaries. A line separates itself from what is not itself; it may divide two entities different from one another. But the curving line is not separable from itself: it is constituted by interdependent surfaces of a simple geometrical figure. By its very nature, the metaphor teasingly invites speculation about what constitutes a boundary.

What was challenging about this from the point of view of Victorian psychology? The metaphor addresses one of its most bothersome conceptual problems, that of the relation between mind and body. This was troubling to the Victorian conceptual imagination for three reasons. First, there was the technical issue of how any interconnection between them might be articulated in terms of a network of physiological and neurological relations. Second, there was the ontological issue of how apparently unlike things - matter and mind - might be understood as a single thing. (The specter of materialism always haunts discussion of this issue.) And third, there is the hornets' nest of ideological issues stirred to alarm whenever such matters were raised. These included: the perceived threat to spiritual values; the contamination of pure mind and the glories of human achievement by connection with the messy (and morally suspect) body; the threat to the special dignity of human creation distinguished from that of the animals; the threat to the sense of superior vocation among Caucasian males; the implied threat to the special autonomy of human consciousness and its ability to exercise free will; the obliteration of sensitive, personal experience by the brute, tawdry, but purportedly 
objective language of science; the alarming proximity of materialist science to materialist (and atheist) politics; and so on. Mind-body interactionists, in short, posited too-close relations between things best kept apart: mind and matter, different species, different races, different ideas, languages, and above all territories of knowledge. The dispute about such issues in the Victorian period always contained an element of intellectual turf-war over who was best fitted to legislate opinion about humankind's most intimate and noble experience. The boundaries between science and religion, and between institutional knowledge in the universities and churches and that developed by the free-lance brigands of opinion publishing in the great periodicals (especially suspect ones like the pro-science Fortnightly Review whose first editor was G. H. Lewes), were patrolled and raided by turns (Rylance).

Dominant psychological opinion - that transmitted by Christian teaching for instance was, by contrast, hierarchical and separatist. The soul was that part of the human personality that governed the remainder of the psychological apparatus. Psychologists in this tradition distinguished the so-called higher faculties, especially those closely related to the soul like reason, faith, a sense of the numinous, moral discrimination, exercise of the will, and so on, from the faculties described as lower, like appetite, sense, emotion, and desire. This structure assumes, first, the control of the lower by the higher, with the related implication that the former are potentially usurpatory and delinquent; second, the separation of mind from body in terms of ontological value; third, a further separation of Western man as a generic being from inferior creatures like, in some accounts, other races or women; and, fourth, the broad exemption of humanity from the complex and ambiguous determinations of nature. In theory, the soul psychologically liberated one from the body, distinguished the special capacities of humanity from those of animals, and - partly as mechanism, partly as unique result - enabled the exercise of choice, free will, and personal self-determination. It drew a boundary between mind and its very many others.

Versions of this hierarchy constituted the orthodoxy of the period. Its ubiquity can be glimpsed in the very etymology of the word psychology which, according to the OED, settled into a recognizable modern usage in the 1840s. Its establishment in mainstream usage identified a modern discipline with scientific ambitions. Yet the meaning of the word in its Greek original is soul discourse, and as such it was widely understood. Coleridge's Encyclopaedia Metropolitana, for instance, completed and published in 1845, a decade after the great man's death, defined psychology in a simple five-word entry as "The Discourse of the Soul." The same line was taken, though at greater length, by most Victorian encyclopaedists (Rylance 22-24). So it is easy to see how G. H. Lewes's boundary-less metaphor offends this orthodoxy by implying uniformity of conceptual structure crossing the boundary between body and soul. But the classic, Christian version of psychological orthodoxy was not the only system in Lewes's sights.

Lewes first conceived of the project that eventually became Problems of Life and Mind in the early 1860s when his working title was "The Soul and its Mechanism," a deliberately goading collation (Kitchel 216). Lewes's provocation was to juxtapose the tradition of souldiscourse with that of iatromechanism, its traditional opponent in post-Renaissance biomedical thought. The iatromechanical tradition regarded the body as a machine (the word means medical machinery), and the psychological version controversially refused to make much distinction between body and mind for key purposes. Taken together, soul-discourse and iatromechanicalism represent the binary pair that established the grounds for debate in much Victorian psychological theory. 
Several senior Victorian intellectuals were iatromechanists, like T. H. Huxley:

Sensation is a product of the sensiferous apparatus caused by certain modes of motion which are set up in it by impulses from without. The sensiferous apparatuses are, as it were, factories, all of which at the one end receive raw materials of a similar kind - namely, modes of motion - while, at the other, each turns out a special product, the feeling which constitutes the kind of sensation characteristic of it. ("Sensation" 269)

Huxley, like Lewes, was a considerable polemicist, and there is, once again, a provoking edge to this. Knowing the delicacy of the issues he is addressing, Huxley enjoys putting the matter as bluntly as possible to nettle the sensitivities of his opponents. (The occasion was a widely reported lecture at the Royal Institution in 1879. It was quickly written up for periodical publication in one of the controversialists' favorite outlets, the prestigious Nineteenth Century.) The late 1870s saw the ascendancy of physiological thinking following a number of pathbreaking discoveries in the cerebral localization of the faculties of sight and language (Daston). But it is only a relatively uninhibited moment in a continuing battle. Huxley's iatromechanicalism was established early, as he records in his autobiography:

my great desire was to be a mechanical engineer, but the Fates were against this; and, while very young, I commenced the study of Medicine under a medical brother-in-law. But, though the Institute of Mechanical Engineers would certainly not own me, I am not sure that I have not, all along, been a sort of mechanical engineer in partibus infidelium... The only part of my professional course which really and deeply interested me was Physiology, which is the mechanical engineering of living machines.... (103)

There could not be a more pungent definition of the iatromechanical tradition than that final phrase: "the mechanical engineering of living machines."

It is easy to embarrass this line of thinking, though - unlike soul discourse - it has been remarkably persistent in mainstream psychological theory beyond the age of steam into that of computers and Artificial Intelligence. Many scientific Victorians took Huxley and others to task for asserting that humans were warm automata. G. H. Lewes did, for instance, as did W. B. Carpenter and William James (Lewes, Study 29-38; Carpenter; James 132-47). But instead of pointing to the category mistakes embedded in the iatromechanical comparison of human to machine, and the elision of questions of consciousness and agency, it may be a more telling question to ask why the idea that human beings were like factories appealed at all. Why did this metaphor appear so captivating to intelligent Victorian people? There seem to be at least three good reasons.

First, it drew on the glamour of astonishing technology. Associations of this kind excite the imagination and, in so doing, purloin evidence of workable hypotheses by referring the unknown directly to the known. According to the historian Georges Canguilhem, nineteenth-century conceptions of nervous physiology "were based in part upon analogies with operations or objects which were familiar by dint of construction and/or use of machines, progress in this branch of physiology, whose discoveries were incorporated into psychology, earned it widespread recognition" (Canguilhem 122-23; also Jeannerod). Thus some neurologists, and the psycho-physiologists who followed them, imagined the nervous system as like the electric telegraph, like controlled explosions, like (as in Huxley) factory 
production lines. Tennyson, in poem CXX of In Memoriam (1850), made a characteristically mournful joke of it:

\author{
I trust I have not wasted breath: \\ I think we are not wholly brain, \\ Magnetic mockeries...
}

"Magnetic mockeries" is sometimes glossed as a reference to Robert Chambers's controversial Vestiges of the Natural History of Creation (1844), where Chambers speculates on the relationship between electricity, magnetism and the operation of the cerebrum (A. L. Tennyson 970-71). But the reference might be more openly topical. Electrical telegraphy works by the alteration of magnetic fields, such that a distant dial may be made to point to specified letters or numbers by controlled fluctuations in electrical current. Such a system was patented in Britain in 1837 and was put extensively into operation during the railway boom of the 1840s as telegraph wires were laid alongside new track. But it was initially notoriously unreliable, in ways not unlike modern voice-to-text recognition systems, producing comical confusions and gobbledegook - hence the "mockeries." Tennyson's reference to technological failure is made in the interests of a position opposed to iatromechanical models and, more generally, the scientific exploration of the mind. "What matters Science unto men, /At least to me?" his poem continues - especially, he implies, as it doesn't work. "No evolutionist," he once sharply remarked to John Tyndall, an arch advocate of the materialist position, "is able to explain the mind of Man or how any possible physiological change of tissue can produce conscious thought" (H. Tennyson 1: 323). For him, the boundary - the barrier - between body and mind was ever thus.

But temporary technological setback, and root-and-branch opposition from conservatives like Tennyson, did not stop the analogy. Alexander Bain, a friend of both Huxley and Lewes, drew an elaborate neurological metaphor from exactly the same source in The Senses and the Intellect (1855), arguably the most influential of nineteenth-century psychological textbooks. What is interesting about Bain's speculation, and what incidentally distinguishes it from Huxley's rather barren image of factory production, is the way telegraphic relays provided the opportunity to imagine networks of connections. Bain envisages not a closed circuit but a system of complex links and "centres" (Bain 30-38). George Dyson has recently argued that it is in the conceptual move from analogies based upon point-to-point or serially sequenced machinery, to ones based upon diversely connected networks, that the modern impetus to think about the origins of intelligence and other higher functions is to be found.

But the appeal of mechanical analogies was not merely a matter of technological glamour. Factories, as in Huxley's image, are also wealth-producers, and iatromechanical theory gained by elaborating conceptual structures that imaged the human person in forms recognizable to authoritative ideologies. In Huxley's metaphor, humans are productive beings in a commercial world. "The most important machine is man," wrote Alfred Marshall, one of the founders of neo-classical Victorian economics, "and the most important thing produced is thought" (Schabas 84; see also McReynolds). Writing this in the 1860s, Marshall was directly influenced by Bain who, in turn, had strong sustained connections with the Millite wing of philosophical radicalism. So iatromechanical ideas attached themselves not just to technological advance, but also to wealth production and a dynamic sense of social mobility. 
We can see a reflection of this in the personnel whose work developed the newly named discipline of psychology. The leading psychologists of the Victorian period were men like Huxley, Bain, Spencer, Carpenter, and Lewes, all of whom hailed from undistinguished social backgrounds. Bain held several university posts, but the others were freelance, unattached intellectuals making their ways, and their ideas, outside the boundaries of established institutions.

The third reason why iatromechanical concepts appealed to Victorian people lies in their heuristic benefit. Machine analogies have the slightly oxymoronic advantage of being not only exciting, but also predictable. Machines are stable systems and can be reverseengineered to demonstrate directly the cause from the effect. Machine analogies take the mysterious and complex and make them comprehensible by familiar comparison by providing clear causal sequences. Though so different in many respects, the iatromechanical and spiritualist traditions of nineteenth-century psychology had in common root conceptual models with fixed structures and clear lines of hierarchy, sequence, and determination. Both drew boundaries around the body. One tradition aimed to transcend it; the other to circumscribe its comprehension by a reductive materialism.

It is therefore not difficult to see why Lewes's alternative metaphor of convex and concave challenged the accepted structures of determining dependency built into both soul-and-body and machine sequence models. To ask of the convex and concave surfaces of a bending plane which has determining priority is a meaningless question. It is this resistance to fixed, boundary-based models of mind that distinguishes the adventure in thinking that is the best of the new Victorian psychology. To give its flavor, here briefly is one of Lewes's characteristic propositions:

the group is never a fixed structure; it is only a disposition of the elements which is easily reformed; just as in a Kaleidoscope there are certain groups of the separate pieces of glass which combine now in one way and now in another, according to impulse. (Problems: Third Series 140-41)

Lewes refers to what he calls "neural groups," the disposition of neurological elements in the system. The conception is inevitably vague, though it is interestingly predictive of some modern thinking on what the Nobel Prize-winning neurobiologist Gerald Edelman calls, with slight variation, "neuronal groups," to which we shall return. For Lewes, as for Edelman, these groups and their functions are produced by patterns of stimulation and activity and not by preestablished disposition: use, being-in-the-world, determines function. So what is striking and strikingly modern - about Lewes's formulation is, firstly, that this is an energy system based upon, as he puts it, "impulse"; secondly, it is a system characterized by variability and adaptability; thirdly, it sees function as a product of selection and iteration not essential property.

This last point is crucial. It identifies an error to which Lewes objected in the work of the path-breaking, early nineteenth-century French physiologist Xavier Bichat, for whose work George Eliot's medical researcher in Middlemarch, Tertius Lydgate, is an enthusiast. Lydgate dreams of discovering human propensities, "the first lurking-places of anguish, mania and crime," through the identification of "primitive tissue" as a cause of character and behavior (194; ch. 16). Lydgate's error - like Bichat's, according to Lewes (Problems: Second Series 27) - is to posit a direct correspondence between histology and personal destiny. "What was the primitive tissue?" Lydgate ponders. But his creator, writing four 
decades later, undercuts his enterprise by remarking that this question was "not quite in the way required by the awaiting answer" (178; ch. 15.). Lydgate's intrepid failure as a scientist (he is at least credited, as Lewes credited Bichat, with fertile error) is to think as both a reductionist and a determinist, which was certainly not Lewes's, or Eliot's, habit of mind. Instead of proposing direct causal correlations, Lewes thinks in terms of emergent properties, and of the ways in which their complexity baffles both immediate conceptual figuration and neat causal sequencing. Thus, in the short passage on "neural groups" quoted above, Lewes, like a number of his sophisticated contemporaries (W. B. Carpenter and William James spring to mind), writes not in terms of entities, but of changed patterns of perception, as in a kaleidoscope. He consistently emphasizes evolving, self-adjusting structures.

This can be a very literary effect. This is partly because it occurs in language, but also because it attempts to express new relationships outside old boundaries. Both Lewes and Eliot specialized in this. Here is her celebrated account of the town of Middlemarch into which Lydgate, her fictional bio-medical researcher, is about to enter:

\footnotetext{
Old provincial society had its share of this subtle movement: had not only its striking downfalls, its brilliant young professional dandies who ended by living up an entry with a drab and six children for their establishment, but also those less marked vicissitudes which are constantly shifting the boundaries of social intercourse, and begetting new consciousness of interdependence. Some slipped a little downward, some got higher footing: people denied aspirates, gained wealth, and fastidious gentleman stood for boroughs; some were caught in political currents, some in ecclesiastical, and perhaps found themselves surprisingly grouped in consequence; while a few personages or families that stood with rocky firmness amid all this fluctuation, were slowly presenting new aspects in spite of solidity, and altering with the double change of self and beholder. Municipal town and rural parish gradually made fresh threads of connection - gradually, as the old stocking gave way to the savings-bank, and the worship of the solar guinea became extinct, while squires and baronets, and even lords who had once lived blamelessly afar from the civic mind, gathered the faultiness of closer acquaintanceship. Settlers, too, came from distant countries, some with an alarming novelty of skill, others with an offensive advantage in cunning. In fact, much the same sort of movement and mixture went on in old England as we find in older Herodotus, who also, in telling what had been, thought it well to take a woman's lot for his starting-point; though Io, as a maiden apparently beguiled by attractive merchandise, was the reverse of Miss Brooke, and in this respect perhaps bore more resemblance to Rosamond Vincy. (122-23; bk. 1, ch. 11)
}

This passage emphasizes movement that, as Eliot pointedly puts it, is "constantly shifting the boundaries." Like Lewes, she invokes complex optical and perceptual effects - the surprising grouping of people presenting new aspects, as in a kaleidoscope, or the "double change of self and beholder" - to register dynamics of change and process and invoke an evolving environment. Thus, as we try to grasp the complex, multi-faceted nature of the activity being described, we are shifted between metaphorical registers: from people slipping and climbing, to optical effects, to economics and, eventually, to the classics. The writing stretches the conceptual framework in a way that both reflects and evokes the emergent world. I suggest that this is an activity cognate with the stretching of the conceptual boundaries in psychology attempted by Lewes and like-minded contemporaries.

What boundaries are at stake here? We might note the following. First, obviously enough, there is the boundary between mind and body or brain. Lewes is an emphatic interactionist, opposing the bounded, hierarchical models of spiritualists and iatromechanists alike. Second, 
there are issues about how causality is modelled in complex systems. The structure figuredit is no more than that - by Lewes is one whose conceptual architecture has much in common with the evolutionary ideas he enthusiastically embraced. It is a world of emergent rather than stable properties, of structural indeterminacy, of fissile, productive messiness. It does not belong to a world of smooth, definable lines with neat boundaries. By contrast Huxley, in his psychological thinking, appears to have thought little of the impact of evolutionary argument on psychological concepts.

But there is a third boundary in play that arises from thinking at the edges of knowledge or, more strictly, the edges of ignorance. These nineteenth-century theorists were working at the speculative edge of the known in scientific and conceptual terms. They were trying to glimpse into being not the details of a known world, but the very terms under which it might be conceived. Lewes and his contemporaries could not describe, either in much detail or with much certainty, the operations of even the rudimentary functions of the brain. Instead, they struggled with the conceptual architecture of ways of looking at the phenomena in which they were interested. It is this - which is in large part not directly a matter of extra-linguistic knowledge - which is often at the forefront of attention in reading these writers. Apropos of this, Kant, who influenced British debate about psychological issues a good deal, has a suggestive phrase in the Introduction to Part One of The Critique of Judgement (1790). He speaks (the context of discussion is exactly the issue of what we can know about the processes of our own minds) of the way in which psychological conceptions are "unfathomable, though still thinkable" (23). It is this sense of being at the edge of issues without certainty of solution that haunts, and enriches, a good deal of Victorian debate. The manifest form of this is the search for conceptual structures beyond old boundaries.

This engages a fourth boundary: that between them and us, the Victorian and the modern, because the conceptual struggle to grasp new forms of relationship between entities like mind and brain whose commensurability is difficult to conceive, is still current. What follows suggests ways in which the boundaries between then and now may be less firm than one might think. Here is another shrewd Victorian commentator on such issues:

\footnotetext{
But between these purely mental inquiries, and those which regard the physical nature of man, there lies an interspace; destined ever to continue such; yet greatly narrowed, we may affirm, by the remarkable discoveries regarding the functions of the nervous system, and their relation to mental as well as physical phenomena, which of late years have given a new character to physiology. While recognising still a line and limit, impassable by human reason or research, we have approached nearer to it on this side, and are justified in believing that the same investigation, further pursued, will bring us closer to the boundary. (Holland 614)
}

Sir Henry Holland was a distinguished figure in Victorian medical and psychological circles. He was also well known to Eliot and Lewes. In fact, he was their doctor. A man of urbane disposition, a celebrated traveller, perhaps a government agent when abroad, widely read and wide thinking, his books, scattered over a long career from the 1830s to the 1880s, provide a commentary on developing arguments in Victorian psycho-physiology (Rylance ch. 4). He was, as a senior member of the medical establishment and the Whig hierarchy, at once an insider and a man of open opinions, including the recognition of psychosomatic illness and its treatment. (Psychosomatic illness, of course, is an instance of mind-body interaction par excellence.) 
His views in this passage are outwardly conformist: "interspace," "line and limit," and "boundary" come from the vocabulary of the classic insistence that mind and matter are distinct. "Interspace" is an unusual choice (it was in fact a very recent word dating, according to the OED, from 1847), but gulfs, gaps, and chasms feature regularly as big obstacles in the way of the adventurous traveller in the conceptual landscape of Victorian psychology. However, this passage is notable in other ways.

One interesting feature is the way it tiptoes around its own problem. It may be (as it formally proposes) that it is "destined" that an "interspace" should ever lie between mind and body, but the choice of that new word is artful. Interspace, in one of its leading senses, means a space put between. It is the act of an agent not of nature. The qualifier about "line and limit" reinforces this. The "line and limit," it turns out, is, as Kant also believed, a feature of our conceptual capacity ("impassable by human reason or research," Holland writes), rather than a matter of ontological antecedence or natural fact. So there is ambivalence at the heart of Holland's attitudes. His approach in fact is caught in an epistemological version of Zeno's paradox. He seems to insist that the boundary is there: real, thick, absolute, and impenetrable. Nonetheless, we seem to get relentlessly closer to crossing it. This asymptotic drift is perhaps mirrored in the loping sentences that seem to advance sneakily by clausal revision, ever closer to that celebrated boundary which the wanderer can never quite cross. There is a kind of trochaic rhythm to his ideas, up and down, as though he wants to assert the conventional wisdom, and accommodate its opposite in a lower tone.

I find Holland's a contextually adroit, rather than evasive, meliorism. It is a supple way of accommodating the classic prejudice in Victorian theory against material explanation. It also confronts the difficulty that scientists were in fact unable to cross these formidable boundaries with demonstrated knowledge. Nowadays many researchers are less prone to caution. Here is Antonio R. Damasio, a widely admired writer on the problem of consciousness, in a symposium on "The Hidden Mind" in a recent issue of Scientific American:

I would be foolish to make predictions about what can and cannot be discovered or about when something might be discovered and the route of discovery. Nevertheless, it is probably true to say that by 2050 sufficient knowledge of biological phenomena will have wiped out the traditional dualistic separations of body/brain, body/mind and brain/mind. (9)

This at least has the virtue of being a testable hypothesis - eventually. But in its bullish way it is treading the same path as Henry Holland towards what now appear to be shrinking boundaries figured by Damasio in the tiny punctual slash marks between "body/brain, body/mind and brain/mind."

However, this cannot be a matter of a more confident and knowledge-rich science bulldozing obstacles. At a conceptual level it still demands careful footwork which indicates in some respects that the problems encountered by Victorian thinkers persist in imposing ways. One leading theorist, the neurobiologist Gerald Edelman, is compelling for present purposes because in some crucial respects his work is conceptually adjacent to initiatives taken by leading Victorian theorists.

That Edelman's ideas do not lend themselves to quick summary is inevitable, but the founding principles are important. Edelman holds that brain structure and brain systems develop their morphology in an evolutionary way through iterative interaction. The brain being composed of multiple sheets of neurons, which of these is selected for use will depend, 
he argues, upon the brain's developmental experience. In the same way that, in biological evolution, certain kinds of reproductive process favor adaptation to, and success in, particular environments, so:

In neuronal group selection, differences in connectivity, synaptic structure, and the morphology of neurons in the primary repertoire, after confrontation with different correlated patterns of signals from the environment, lead to differences in the probabilities of their responses as groups. This reflects changes in the patterns of their synaptic strengths. There is differential reproduction in one case [biological evolution], differential amplification in the other [neuronal group selection]. (97)

These ideas make demands. They require some specific knowledge (for example, that a neuron is a nerve cell and a synapse the connection between neurons), as well as an awareness that the brain functions as a structure by virtue of millions of interacting synaptic connections. The individual character of this functioning is related to the nature of these interactions. But the important leap is conceptual. Edelman is reflecting upon how particular, functioning structures arise from multiple potentials. In biological evolution reproduction regulates change. But the long temporal dimension does not apply to the evolutionary morphology of the individual brain. It is not a question, therefore, of death and replacement. Instead, as Edelman says, it is an issue of the relative amplification of certain elements. The brain's structure, and the psychological systems that attend it, evolve in experience. The activation of certain neuronal groups leads to further use through reiteration: "Nervous system behaviour is to some extent self-generated in loops; brain activity leads to movement, which leads to further sensation and perception and still further movement. The layers and loops between them are the most intricate of any object we know, and they are dynamic; they continually change" (29).

Edelman has an arresting metaphor for this: "the chemical and electrical dynamics of the brain," he writes, "resemble the sound and light patterns and the movement and growth of a jungle more than they do the activities of an electric company" (29). Thus, his thinking breaks sharply from the iatromechanical tradition. His conception depends upon multiple populations, amongst which selection occurs, rather than the lean, cased systems of machines. These are self-developing, adaptable, self-revising processes whose agency is the selections made amongst vast variety and possibility. Machine systems cannot tolerate this degree of indeterminacy. Edelman's ideas require spacious structures envisaged as networks or ecosystems like a jungle rather than taut hierarchies and elegant command sequences. When imagining such structures, boundaries inevitably become leaky because in networks it is hard to distinguish where one component ends and another begins. Evolutionary eco-systems can only operate with diverse, multi-sided interactions. In this context it makes little sense to maintain any but the most porous sense of boundaries either between phenomena, or between the stages of a process. A different kind of conceptual environment is in play. Edelman's own metaphors, sampled above, give the lead: groups, layers, loops, patterns, jungles.

Edelman describes, in complex and detailed ways, the evolution of sophisticated higher order activities such as perception and memory on this basis. Once the system of organized correlations between sheets of neurones gets to a certain complexity and sophistication, the system is not only able to correlate data from diverse sources to generate multi-aspect brain maps of things and events, it is also able to re-enter these structures to reorganize information. It has been claimed that Edelman has still not answered the pressing question about what 
consciousness is, as a qualitatively and maybe ontologically distinct property, in a system that would appear to function happily without it (Searle 48-51). Nevertheless, these ideas carry major implications for how psychological concepts are developed.

One major implication is that concepts do not, as in some classical theories of categorization, arise by natural self-election from phenomena themselves. Instead they are products of selection amongst alternatives. For example, recognition, either at the level of the neurone or as a cognitive act, carries little of distinctive informational or instructive value for Edelman. It is, he says, "a kind of adaptive matching" against a population of available alternatives (81). This does not mean that perception and conceptualization occur by some crude best fit principle whereby new experience is shoehorned into existing, more or less ill-fitting categories. If that were so, the generation of new ideas would be a clumsy, plodding and probably dysfunctional business.

Instead, for Edelman, categorizations, concept formation and the symbolic structures that express them, are the products of selective refinement and integration amongst what, from one point of view, appear to be fraying and inconstant elements. Edelman has no patience with smooth computer models: "Psychological work indicates . . that computer views of the mind cannot deal with categories of the mind and of language (see any poem) that fail to reflect categories in the world. Individuals understand events and categories in more than one way and sometimes the ways are inconsistent" (236-37). What he calls the objectivist view of cognition and language (the view that symbolic or conceptual entities directly "correspond to entities and categories in the world" [232]) breaks down because it cannot operate at the fuzzy edge of understanding, at the point where concepts, categories and symbols become hybrid or disheveled, but still remain productive. In language, metaphor - "the referral of the properties of one thing to those of another in a different domain" (237) - is a creative case in point. But it is only a special instance of a general truth:

Meaning simply refuses to be bound by a fixed set of terms in a specific coding system.... the mind is not a mirror of nature. Thought is not the manipulation of abstract symbols whose semantics are justified by unambiguous reference to things in the world. Classical categories do not serve in most cases of conceptual categorisation and they do not satisfactorily account for the actual assignment of categories by human beings. There is no unambiguous mapping between the world and our categorization of it. (237)

The convergence between these propositions and those of G. H. Lewes and some of his contemporaries is striking. Lewes, it will be recalled, also developed a theory of "neural groups" in which "the group is never a fixed structure; it is only a disposition of the elements which is easily reformed." He too pictured a dynamic and morphologically evolving system; he too shared George Eliot's need to revise conceptual categories actively in language to keep pace with (to adapt Edelman slightly) the "ambiguous mapping between the world and our categorization of it."

What I am pointing to is not a matter of prolepsis or even ancestry. It is a shared quality of intellectual enquiry. It may be possible for the intellectual historian to follow a detailed route between, say, Lewes, William James (who learned much from Lewes), and Edelman who takes James as inspiration. (James's influential redefinition of consciousness as a process rather than a substance is a key step [Edelman 37]). But this is beside my point, and in any case the tools of the trade in neurobiology, and the range and depth of scientific knowledge, 
have changed so enormously it would be no more than tracing the resemblances between a coracle and a catamaran. Both may float, but they do so in different waters.

Instead it is, as I say, a question of modes of inquiry, of how, especially at points of change in the ways in which the human mind is understood, conceptual structures are revised and old boundaries give way. The work of William James is a landmark for many reasons: not least in the way he crossed and re-crossed the boundaries between European and American thought as well as those between the psychology of consciousness and the neurobiological basis. In "The Functions of the Brain," one of the less well-known chapters of his Principles of Psychology (1890), we see him trying to evoke a pluralistic, multi-faceted environment. What are particularly interesting are his efforts to evoke and refine elusive concepts in language:

\begin{abstract}
We thus see that the postulate of Meynert and Jackson which we started with on p. 41 is on the whole most satisfactorily corroborated by subsequent objective research. The highest centres do probably contain nothing but arrangements for representing impressions and movements, and other arrangements for coupling the activity of these arrangements together. Currents pouring in from the sense-organs first excite some arrangements, which in turn excite others, until at last a motor discharge downwards of some sort occurs. When this is once clearly grasped there remains little ground for keeping up that old controversy about the motor zone, as to whether it is in reality motor or sensitive. The whole cortex, inasmuch as currents run through it, is both. All the currents probably have feelings going with them, and sooner or later bring movements about. In one aspect, then, every centre is afferent, in another efferent, even the motor cells of the spinal cord having these two aspects inseparably conjoined. Marique, and Exner and Paneth, have shown that by cutting round a 'motor' centre and so separating it from the influence of the rest of the cortex, the same disorders are produced as by cutting it out, so that really it is only the mouth of the funnel, as it were, through which the stream of innervation, starting from elsewhere, pours; consciousness accompanying the stream, and being mainly of things seen if the stream is strongest occipitally, of things heard if it is the strongest temporally, of things felt, etc., if the stream occupies most intensely the 'motor zone'. It seems to me that some broad and vague formulation like this is as much as we can safely venture on in the present state of science; and in subsequent chapters I expect to give confirmatory reasons for my view. (73)
\end{abstract}

The "postulate" that first appears at page 41 is one of systemic parallelism in the psycho-physiological apparatus. Just as sensory and motor systems operate in tandem, so do sensations and ideas. Indeed: "There is complete parallelism between the two analyses," writes James, and he presents a diagram of the sensory and ideational response of a child touching a candle flame. The key point is that "the same diagram of little dots, circles, or triangles joined by lines symbolizes equally well the cerebral and mental processes: the dots stand for cells or ideas, the lines for fibres or associations." Compared to Edelman this is crude (as James realized: he adds "we shall have later to criticize this analysis so far as it relates to the mind"). It appears to posit an identity between cells and ideas, as though the former were simply material encapsulations of the latter. But it is a clear expression of the identity theory: that mental and physical are, as Lewes put it, the convex and concave of one bending plane.

In the more substantial quotation we see a more sophisticated rendering of this. Ideas are no longer crudely embodied in cells. Instead the brain is a structure exchanging and manipulating information and representations (the key sentence is the one italicized by James). The idea is once more close in conception to that of Edelman. The rest of the passage embellishes it. Again, the key principles are those of identity and parallelism: "In 
one aspect, then, every centre is afferent, in another efferent." Afferent nerves are those that transmit inward; efferent are those that transmit outward. James's point is that the "centres" he is trying to describe can be both, and the metaphor he chooses is optical, like that adopted by George Eliot in the passage from Middlemarch cited above. Looked at one way the phenomenon appears like this, looked at another way it appears like that - like the concave and convex sides of a plane. This is not a question of crossing a boundary from one state to another, but of changing the aspect with the function.

I would argue that the rest of this passage embodies this idea as rhetoric. As James says, we are dealing with "a broad and vague formulation," the only kind the science of his day will permit. What is therefore striking about the passage is the congeries or aggregation of metaphors he uses. This rhetorical habit is common in James (the quotation might, in fact, be expanded over several pages, or other examples produced [see for instance 112-14 on the physiology of habit]). The careful citation of references gestures towards secure empirical support, but in fact they only punctuate a restless evocation of a neurological system that is really a new conceptual environment, a way of thinking rather than a product of discovery. In this case - in fact in almost all such cases in James - this is an energy system, and its nature is suggested by dynamic verbs and rapidly switching metaphors. Thus, here, we have excited energy exchange in various forms: running motors and engines, flowing and cascading water, networks of sluices and funnels, electricity. Deliberately, it is unclear whether the "currents" mentioned in the passage belong to water or to electricity. In fact the two were closely related and James exploits the equivocation. Nineteenth-century electrical engineers understood the movement of current directly on analogy with that of water. One form this took was the habit, in Victorian circuit diagrams, of indicating the current's direction by drawing small swimmers alongside the lines representing the wiring. In James's evocation of this amorphous conceptual environment, even the boundaries between forms of matter and energy appear dangerously to dissolve.

And so we come to the last of the boundaries addressed by this essay. Because Victorian thinking about mind-body interaction, and about the conceptual architecture appropriate to describe it was, as James put it, a matter of "broad and vague formulations," it follows that, in part, these are issues of rhetorical management. This is not a disparaging assessment (nor does it imply, as Edelman's jungle indicates, that modern conceptions are free of this). But it is one that brings us close to the boundary that purportedly separates science from literature. In the Victorian period one can observe similar conceptual reconfigurations as writers of both literary and psychological texts try to grasp the mind as a new object of knowledge. We might expect this in George Eliot, who has already been cited. But she is far from alone. Here is another:

\footnotetext{
I knew what the result of such an experiment would be. I, to whom nature had denied the impromptu faculty; who, in public, was by nature a cypher; whose time of mental activity, even when alone was not under the meridian sun; who needed the fresh silence of morning, or the recluse peace of evening, to win from the Creative Impulse one evidence of his presence, one proof of his force; I, with whom that impulse was the most intractable, the most capricious, the most maddening of masters (him before me always excepted) - a deity, which sometimes, under circumstances apparently propitious, would not speak when questioned, would not hear when appealed to, would not, when sought, be found; but would stand, all cold, all indurated, all granite, a dark Baal with carven lips and blank eyeballs, and breast like the stone face of a tomb; and again, suddenly, at some turn, some sound, some long-trembling sob of the wind, at some rushing past of an unseen stream of electricity, the irrational
} 
demon would wake unsolicited, would stir strangely alive, would rush from its pedestal like a disturbed Dagon, calling to its votary for a sacrifice, whatever the hour - to its victim for some blood or some breath, whatever the circumstance or scene - rousing its priest, treacherously promising vaticination, perhaps filling its temple with a strange hum of oracles, but sure to give half the significance to fateful winds, and grudging, to the desperate listener even a miserable remnant - yielding it sordidly, as though each word had been a drop of the deathless ichor of its own dark veins. (Brontë 445; ch. 30)

This is from Charlotte Brontë's Villette (1853). It is a characteristic piece of psychological self-analysis by Lucy Snowe written at a period when introspection was still regarded in mainstream opinion as the chief means of arriving at psychological knowledge. Indeed the passage uses some of the features of orthodox psychological reportage: the use of "faculty" in the second sentence was a semi-technical term as we have seen, and psychological writing was accustomed to capitalizing entities such as "Creative Impulse," as here. (There is also the question of the broader vocabulary - indurated, vaticination, Baal, Dagon, ichor, estrade, for example - which makes a particular kind of unusual technical demand.) But there are two features of this passage to which I wish to call particular attention. The first is that this is once again, as with James and Lewes, a turbulent, energy-filled evocation of mind, one that switches its attention from the relatively passive notion of the faculty (i.e., the mind's tranquil, native attribute) to the stormy issue of a driving "Impulse" (also Lewes's key word) which is changing and creating perception. The second feature is that, as with James (or indeed George Eliot), the revisionary understanding the passage proposes is matched not only by vigor in syntax and tone, but by turbulence in metaphor and register, as though the conceptual foundations for understanding are being inconclusively but necessarily reworked. Thus there is a hectic metaphorical slide: from deities, to rock, to statuary, to wind, to the water and electricity duo again, to demons, to a scene of sacrifice. Each of these has its own distinctive, signifying impact that could be elaborated (the paganism, for instance, is very striking). But the major point is the headlong, revisionary change the passage enacts, as though there were no clear, sufficient ways of describing the mind's activity other than by, in a somewhat Romantic spirit, mutations in the terms of understanding.

Charlotte Brontë was not concerned to make a contribution to psychological theory. This writing is therefore in some respects quite unlike the kind of thing that Lewes or James undertook. But it is a substantial collateral indication of the way in which many Victorian writers, working in adjacent areas, undertook exciting and comprehensive revisions to the boundaries of accepted understanding in psychological issues. This in itself is part of a much larger change in Victorian thinking, one succinctly described by Louis Menand in The Metaphysical Club, his recent, exhilarating history of philosophical pragmatism. It is, Menand argues, a change between thinking in terms of "types and essences, which is prescriptive" to that in terms of the "language of statistics and probability, which is predictive." In this new cognitive environment: "Relations will be more important than categories; functions, which are variable, will be more important then purposes, which are fixed in advance; transitions will be more important than boundaries; sequences will be more important than hierarchies" (123-24). It is this larger change to which Victorian psychological thinking contributed and responded in such an enlivening way. That the issues they raised persist is no matter for regret. It is an essential fact about self-understanding. 


\section{WORKS CITED}

Bain, Alexander. The Senses and the Intellect. London: John W. Parker \& Son, 1855.

Brontë, Charlotte. Villette. Ed. Mark Lily. London: Penguin, 1979.

Canguilhem, Georges. A Vital Rationalist: Selected Writings. Ed. François Delaporte. Trans. Arthur Goldhammer. New York: Zone Books, 1994.

Carpenter, W. B. "On the Doctrine of Human Automatism." Contemporary Review 25 (1875): 397-416.

Damasio, Antonio R. "How the Brain Creates the Mind." Scientific American 31 (August 2002): 9.

Daston, Lorraine J. "British Responses to Psycho-Physiology, 1860-1900." Isis 69 (1978): 192-208.

Dyson, George. Darwin Among the Machines. London: Allen Lane, 1998.

Edelman, Gerald. Bright Air, Brilliant Fire: On the Matter of the Mind. London: Penguin, 1994.

Eliot, George. Middlemarch: A Study of Provincial Life. Ed. W. J. Harvey. Harmondsworth: Penguin, 1965.

Holland, Henry. Medical Notes and Reflections. 3rd ed. London: Longman, Brown, Green and Longmans, 1855.

Huxley, T. H. "Autobiography." Charles Darwin and T. H. Huxley: Autobiographies. Ed. Gavin de Beer. Oxford: Oxford UP, 1983

- "On Sensation and the Unity of Structure of the Sensiferous Organs." Science and Culture and Other Essays. London: Macmillan, 1892.

James, William. The Principles of Psychology. London: Harvard UP, 1981.

Jeannerod, Marc. The Brain Machine: The Development of Neurophysiological Thought. Trans. David Urion. London: Harvard UP, 1985.

Kant, Immanuel. The Critique of Judgement. Trans. James Creed Meredith. Oxford: Oxford UP, 1952.

Kitchel, Anna Theresa. George Lewes and George Eliot: A Review of the Records. New York: John Day, 1933.

Lewes, G. H. Problems of Life and Mind: First Series: The Foundations of a Creed. 2 vols. London: Trübner, 1874.

- Problems of Life and Mind: Second Series: The Physical Basis of Mind. London: Trübner, 1877. - Problems of Life and Mind: Third Series: Problems II, III and IV. London: Trübner, 1879.

- The Study of Psychology: Its Object, Scope and Method. Boston: Houghton, Osgood and Co., 1879.

McReynolds, Paul. "The Motivational Psychology of Jeremy Bentham." Journal of the History of the Behavioural Sciences 4 (1968): 230-44.

Menand, Louis. The Metaphysical Club. London: Flamingo, 2002.

Rylance, Rick. Victorian Psychology and British Culture 1850-1880. Oxford: Oxford UP, 2000.

Schabas, Margaret. "Victorian Economics and the Science of Mind". Victorian Science in Context. Ed. Bernard Lightman. London: U of Chicago P, 1997.

Searle, John R.. The Mystery of Consciousness. London: Granta, 1998.

Tennyson, Hallam. Alfred Lord Tennyson: A Memoir by His Son. 2 vols. London: Macmillan, 1897.

Tennyson, Alfred Lord. The Poems of Tennyson. Ed. Christopher Ricks. London: Longmans, 1969. 